\title{
Effects of binaural beats and isochronic tones on brain wave modulation: Literature review
}

\author{
Sandro Aparecido-Kanzler ${ }^{*}$, Francisco J. Cidral-Filho², and Rui D. Prediger ${ }^{1,3}$ \\ ${ }^{1}$ Department of Neuroscience, Center of Biological Sciences, Federal University of Santa Catarina (UFSC), Florianopolis; ${ }^{2}$ Experimental Neuroscience \\ Laboratory (LaNEx), University of Southern Santa Catarina (UNISUL), Palhoça, Santa Catarina; ${ }^{3}$ Department of Pharmacology, Center of Biological \\ Sciences, Federal University of Santa Catarina (UFSC), Florianopolis. Brazil
}

\begin{abstract}
This systematic review is dedicated to deepening the study of two phenomena: binaural beats and isochronic tones. Data from the scientific literature suggest the existence of a promising therapeutic potential in neurology and psychophysiology due to their influence on specific frequencies of brain waves and their implications for mental health and homeostasis of brain neurotransmitters. Prolonged audio stimuli in repetitive and synchronized manner may induce changes in brain waves patterns and, consequently, modulating neurophysiological, and behavioral responses. The literature review was conducted using PUBMED, MEDLINE, LILLACS, and SCIENCE DIRECT online platforms using the search words: "audio brain entrainment,"'auditory beat stimulation, "'binaural beats,"'brainwave entrainment (BWE)," and "isochronic tones."The search yielded 674 studies, of which 49 were in duplicate, and 592 were out of the scope of this review, and, therefore, were excluded from the study. The remaining studies were analyzed according to the Cochrane Handbook for Systematic Reviews, resulting in 33 randomized, controlled clinical trials that were then evaluated by the Jadad scale. From that, 17 studies obtained a score of three points or more on the Jadad scale. These studies were fully read and critically analyzed. Binaural beats were used in 15 studies (88.25\%), whereas isochronic tones were used only in two studies $(11.76 \%)$. Although most of the studies reviewed here indicated audio BWE effectiveness, some positive outcomes may require further investigation, with more refined and appropriate evaluation tools, better suited for each specific type of intervention and/or therapeutic target. Considering these limitations, the performance of additional studies with more adequate experimental design and data analysis is recommended, particularly focusing on the neurophysiological and behavioral effects of brain wave entrainment on mental states.
\end{abstract}

Key words: Audio brain entrainment. Binaural beats. Brainwave entrainment. Isochronic tones.

\section{Efectos de los tonos binaurales y isocrónicos en la modulación cerebral: Revisión de la literatura}

\section{Resumen}

Esta revisión sistemática está dedicada a profundizar en el estudio de dos fenómenos: latidos binaurales y tonos isocrónicos. Los datos de la literatura científica sugieren la existencia de un potencial terapéutico prometedor en neurología y psicofisiología debido a su influencia en frecuencias especificas de ondas cerebrales y sus implicaciones para la salud mental y la homeostasis de los neurotransmisores cerebrales; los estímulos de audio repetitivos y sincronizados pueden inducir cambios en los patrones de ondas cerebrales y modular las respuestas neurofisiológicas. La revisión de la literatura

\section{Correspondence:}

*Sandro Aparecido-Kanzler

E-mail: kanzlersa@gmail.com
Date of reception: 15-09-2020

Date of acceptance: 17-05-2021

DOI: 10.24875/RMN.20000100
Available online: 15-11-2021

Rev Mex Neuroci. 2021;22(6):238-247 www.revmexneurociencia.com 2604-6180/ C 2021 Academia Mexicana de Neurología A.C. Published by Permanyer. This is an open access article under the CC BY-NC-ND license (http://creativecommons.org/licenses/by-nc-nd/4.0/). 
se realizó con plataformas en línea PUBMED, MEDLINE, LILLACS y SCIENCE DIRECT, con las palabras de búsqueda: "arrastre cerebral de audio","estimulación del ritmo auditivo,"'ritmos binaurales,"“arrastre de ondas cerebrales" y "tonos isocrónicos". La búsqueda produjo 674 estudios, de los cuales 49 estaban duplicados y 592 estaban fuera del alcance de esta revisión y fueron excluidos. Los estudios restantes se analizaron de acuerdo con el Manual Cochrane de Revisiones Sistemáticas, que tuvo como resultado 33 ensayos clínicos controlados aleatorios que fueron evaluados por la escala de Jadad. A partir de esto, 17 estudios obtuvieron una puntuación igual o superior a tres puntos y fueron leídos íntegramente y analizados críticamente. Los tonos binaurales se utilizaron en 15 estudios (88. 25\%) y los tonos isocrónicos sólo en 2 estudios (11. 76\%). Aunque la mayoría de los estudios revisados demuestran la eficacia del arrastre de ondas cerebrales, algunos resultados pueden requerir más investigación con herramientas más refinadas y apropiadas, para cada intervención y/u objetivo terapéutico. Teniendo en cuenta estas limitaciones, se recomienda que se lleve a cabo un diseño experimental y análisis de datos más adecuados, centrándose en los efectos neurofisiológicos del arrastre de ondas cerebrales y los estados mentales.

Palabras clave: Estimulación cerebral con audio. Tonos binaurales. Arrastre de ondas cerebrales. Tonos isocrónicos.

\section{Introduction}

Brain waves consist of rhythmic patterns of neuronal activity or synchronized electrochemical pulses from groups of neurons in the central nervous system (CNS) ${ }^{1}$. There are several well-established brainwave range patterns: gamma $(30-70 \mathrm{~Hz})$, beta $(13-30 \mathrm{~Hz})$, alpha (8$13 \mathrm{~Hz})$, theta $(4-8 \mathrm{~Hz})$, and delta $(1-4 \mathrm{~Hz})^{2}$. Each one of these frequency bands has been correlated with different states of consciousness, such as awake, relaxed, rapid eye movement (REM) sleep, as well as non-REM sleep stages ${ }^{3}$.

According to Gruzelier ${ }^{4}$, prolonged audio stimuli in repetitive and synchronized manner may induce changes in brain waves patterns and, consequently, may modulate neurophysiological and behavioral responses. More specifically, repetitive external or environmental stimuli may temporarily affect the predominance of specific brain wave frequencies, a phenomenon namely brainwave entrainment $(B W E)^{5-7}$. Therefore, BWE can be defined as rhythmic synchronization of brainwave oscillation with an external repetitive stimulus.

BWE is a recurrent phenomenon in nature and biologically present in living beings ${ }^{8}$. The principle of entrainment or harmonization was discovered around 1665, by the Dutch scientist Christian Huygens ${ }^{9}$. The synchronization obtained through the entrainment principle is the result of the harmonization principle, a physical phenomenon that occurs systematically in nature, and that is dependent on environmental stimuli, for example, visual, auditory, or tactile. These stimuli may be used to elicit synchronized brainwave patterns to match that of different mental states and/or levels of consciousness, as seen with data acquisition techniques, such as the electroencephalography (EEG). In this context, Oster ${ }^{10}$ stated the possibility to improve, amplify or modulate brain wave patterns to conditioned events in the cerebral cortex ${ }^{3,11}$. The proposed therapeutic benefits have a wide scope, including the improvement of cerebral blood flow, neuroplasticity stimulation, and neurophysiological compensations between the cerebral hemispheres ${ }^{3}$.

In this review, we focused on the most common forms of auditory BWE, that is, binaural beats and isochronic tones. Acoustic waves are characterized in Hertz (number of cycles per second). The audible sound spectrum for humans comprises frequencies between $20 \mathrm{~Hz}$ and $20,000 \mathrm{~Hz}$, regardless of its complexity, and as long as it has an amplitude greater than $0 \mathrm{~dB}$ (decibel) ${ }^{12,13}$.

Isochronic tones consist of distinct and repetitive regular beats of a single tone. The number of peaks per second in the signal amplitude is the isochronic frequency heard at regular and standardized time intervals. On the other hand, binaural beats represent the auditory experience that occurs when two sounds of close frequencies are presented separately to each ear with headphones or stereo speakers. The brain integrates the two signals, producing a third "phantom sound" representing the difference between the two auditory stimuli. For example, if a frequency of $114 \mathrm{~Hz}$ is presented to the right ear, and another of $124 \mathrm{~Hz}$ to left ear, a binaural beat of $10 \mathrm{~Hz}$ is created by the brain as a result of these stimuli. In this case, brain waves tend to match the binaural beat frequency, in this example $10 \mathrm{~Hz}$, which corresponds to alpha brainwave pattern. Binaural beats are created in the superior olivary nucleus of the brain stem, the local of contralateral integration of auditory input ${ }^{14}$ (Fig. 1).

The beat is neurologically transported to the reticular formation, which uses neurotransmitters to trigger changes in brain wave activity ${ }^{10}$ that synchronizes with that of the stimulus generated. The mental features 


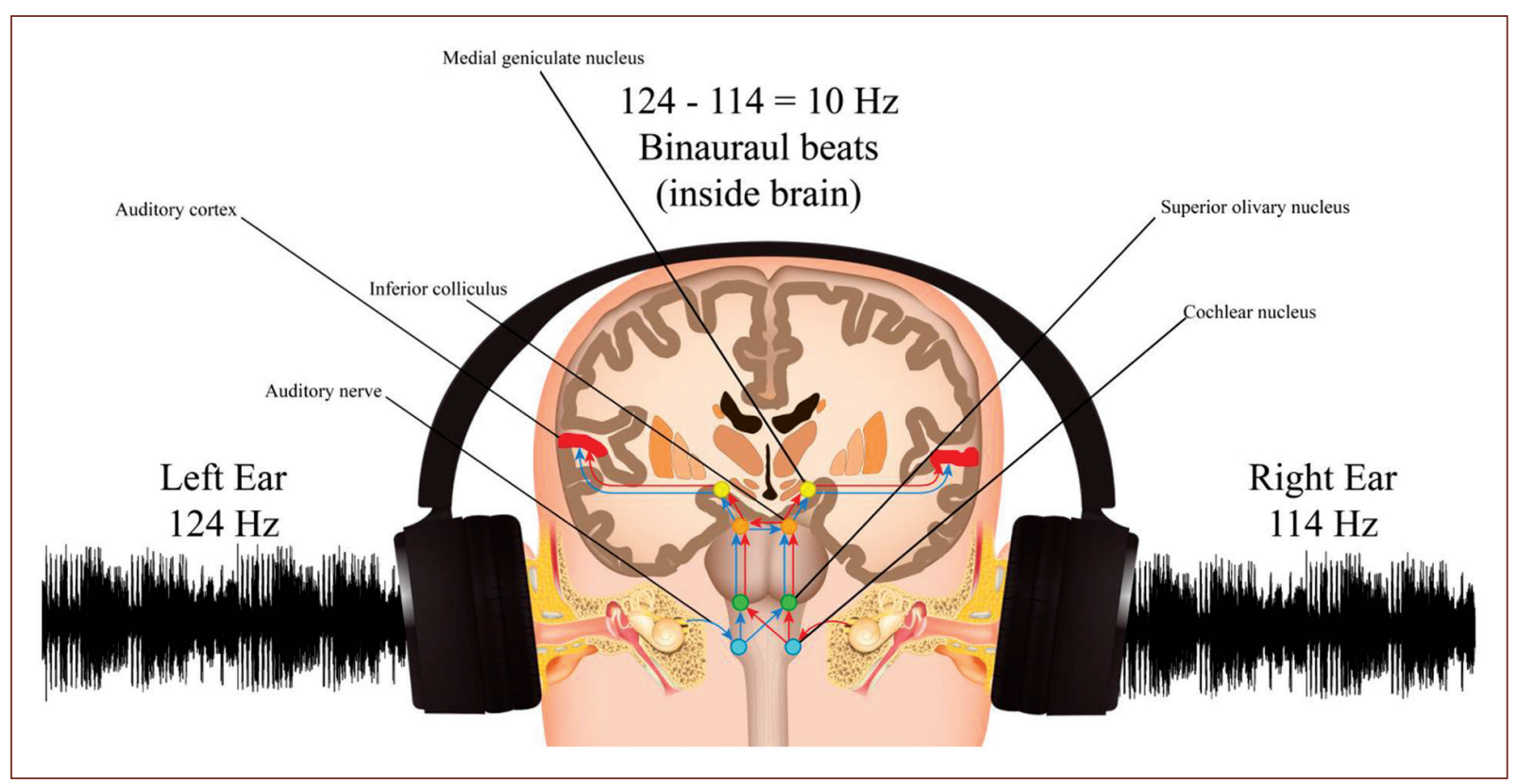

Figure 1. Binaural beats generated by the brain.

associated with each brain wave pattern can be elicited based on the scientific principle of harmonization, also known as "brain wave entrainment."

Most of studies with binaural beats and isochronic tones provides positive outcomes, indicating that audio brain entrainment may yield different benefits, both physically and mentally ${ }^{15,16}$. More specifically, brain entrainment can be applied to induce mental states and as adjunctive treatment to several brain disorders in a safe and non-invasive manner, such as for the treatment of depression and anxiety disorders ${ }^{17}$. For instance, it was demonstrated that a group of individuals exposed to $6 \mathrm{~Hz}$ sounds for 10 min presented a significant increase on theta wave $(4-8 \mathrm{~Hz})$ cortical activity in comparison to control group that did not receive the stimulus. These findings indicate a facilitatory effect on induction of a meditative state and altered states of consciousness $^{18}$. In this context, the aim of this study was to review the scientific evidence on the therapeutic use of binaural beats and isochronic tones for the modulation of brain wave patterns and mood states.

\section{Development}

\section{Methodology}

The central question of the current study was: what are the therapeutic and/or neuroplastic and behavioral effects of binaural beats and isochronic tones on brain wave patterns and mood state modulation?

The following electronic databases were used for the studies search: PUBMED, MEDLINE, LILLACS, and SCIENCE DIRECT, and the following search words (key words) were used: "audio brain entrainment," "auditory beat stimulation," "binaural beats," "BWE," and "isochronic tones."

The bibliographic search was conducted independently by the authors from October to December 2019 , and blindly to the results obtained by the other authors. The studies that met inclusion criteria (see below) were later compared and compiled. The Cochrane Handbook for Systematic Reviews ${ }^{19}$ recommendations were followed to assess the risk of bias; and the Jadad scale ${ }^{20}$ to evaluate methodological quality. The Jadad scale consists of five criteria items, ranging from 0 to 5 points. A score below 3 indicates low methodological quality and a score of 3 points or more indicates superior methodological quality. The scale consists of the following questions:

1. Was the study randomized?

2.Was the randomization method appropriate?

3. Was the study blinded? Double blinded?

4. Was the blinding method appropriate?

5. Were drop-offs properly reported?

For questions 1,3 , and 5 , a single point for yes, or zero for no, is assigned. For questions 2 and 4 , a single point for the use of the appropriate method, zero points for no 
description of the method, or a single negative point for the inappropriate use of the method is assigned.

\section{Inclusion criteria}

The following criteria were included in the study:

1. Publication date: studies published from 2009 to 2019

2. Study design: clinical studies, such as case report, case series, case-control study, non-randomized controlled clinical trial, and randomized clinical trial

3. Population: without limitation

4. Intervention: stimulation with binaural beats or isochronic tones

5. Comparison: without limitation

6. Result: qualitative and quantitative.

\section{Results}

The search yielded a total of 674 studies (PUBMED: 74; MEDLINE: 396; LILLACS: 138; and SCIENCE DIRECT: 66). As illustrated in figure 2, from the total of studies, 49 studies were in duplicate, and 592 studies addressed other themes beyond the scope of this review, and, therefore, were excluded from the study.

The selected studies were analyzed according to the Cochrane Handbook for Systematic Reviews ${ }^{19}$, resulting in 33 randomized, controlled clinical trials that were then evaluated by the Jadad scale ${ }^{20}$ (Fig. 3). Only 17 studies obtained a score of three points or more on the Jadad scale ${ }^{20}$, and them were fully read and critically analyzed; studies are summarized in Table 1. Binaural beats were used in 15 studies (88.25\%) whereas isochronic tones were used in only two studies (11.76\%) (Fig. 3). In $82.35 \%$ of these publications monaural and/ or binaural audio stimulation were more effective in comparison to control group.

After the evaluation made by the Jadad scale, the 17 selected studies were classified according to the methodological criteria adopted in each experiment (Randomized Study (R); Double Blind Study (BD), Controlled Study with Placebo (PC), type of sample and number of individuals in the study and results obtained by each researcher. The summary of therapeutic targets and forms of intervention and approaches of these selected studies are described in Table 2.

\section{Main findings of the studies addressing the effects of brain waves on mental states}

In this section is presented a description of the different brainwaves, their effects, and the discussion of the main findings obtained in the studies reviewed here. The study performed by Washington and collaborators ${ }^{21}$ indicated that each brain wave frequency produces particular neurophysiological and cognitive effects, been associated with a specific state of consciousness.

Delta waves (< 4 Hertz): the slowest waves are associated with the deepest state of sleep and unconscious. These waves represent the ideal for sleep, physical and mental recovery, and deep meditation. Delta waves lead to a state of mental happiness and empathy where the person feels more connected with her/himself. This state improves intuition and memory. Delta waves are associated with the release of growth hormone ${ }^{22}$, which is beneficial for cell regeneration, as well as the production of endogenous opioids ${ }^{23}$. None of the selected studies review here used delta waves.

Theta waves $(4-8 \mathrm{~Hz})$ : this frequency pattern is related to the processes of creativity, enhanced intuition, more intense emotional connections that elevate sensitivity, and a sense of tranquility and reduced anxiety. Theta waves also contribute to the improvement of problem-solving skills and retention of much larger amounts of information in shorter period of time. This pattern is associated with decreased levels of serum cortisol and with the modulation of serotonin and melatonin. Theta waves generate a relaxed state of consciousness 24,25 .

Eight of the studies reviewed here were conducted with Theta waves, with binaural beats as well as isochronic tones interventions. Major targets were cognitive and/or pathological states. Increased long-term memory performance was observed in patients with epilepsy who underwent 6-min $5 \mathrm{~Hz}$ brain entrainment sessions, once a week for 6 weeks with binaural and isochronic tones ${ }^{26}$. On the other hand, in non-epileptic adult subjects, $15-\mathrm{min} 5 \mathrm{~Hz}$ brain entrainment sessions did not induce significant effects ${ }^{27}$. Visuospatial working memory and cortical connectivity were not altered following a single intervention of 5 min with $5 \mathrm{~Hz}$ thera$\mathrm{py}^{28}$. Another study using binaural beats also describes absence of significant effects in the working memory of healthy young adults ${ }^{29}$. Interestingly, $20-\min 6 \mathrm{~Hz}$ binaural beat entrainment twice a week for 14 days effectively reduced the perception of pain severity ${ }^{16}$.

In addition, in patients with temporal lobe epilepsy who underwent brain implants with EEG signal control, acute therapy of temporolateral ( $5 \mathrm{~Hz}$ for $5 \mathrm{~min}$ ) increased memory acuity with EEG synchronization ${ }^{17}$. Moreover, in young adult's post-physical training, binaural beat entrainment (4-7 Hz for $20 \mathrm{~min}$ ) increased parasympathetic 


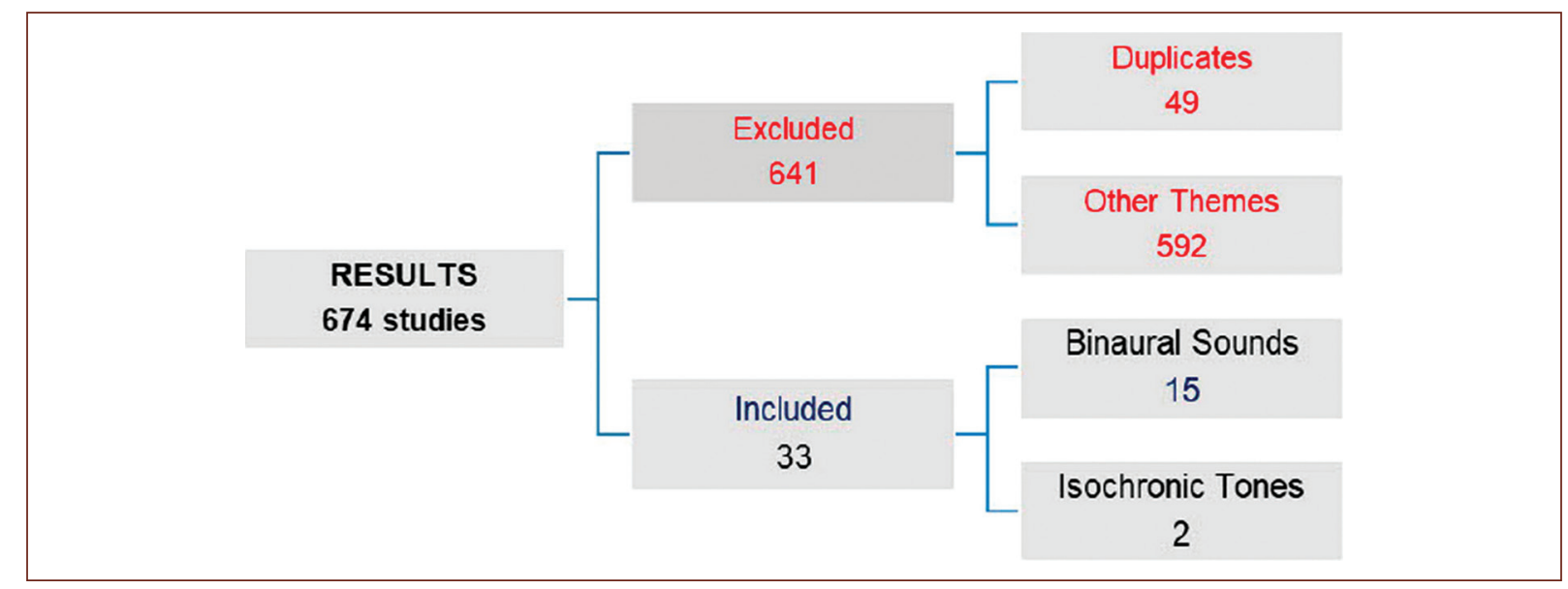

Figure 2. Randomization algorithm and study selection.

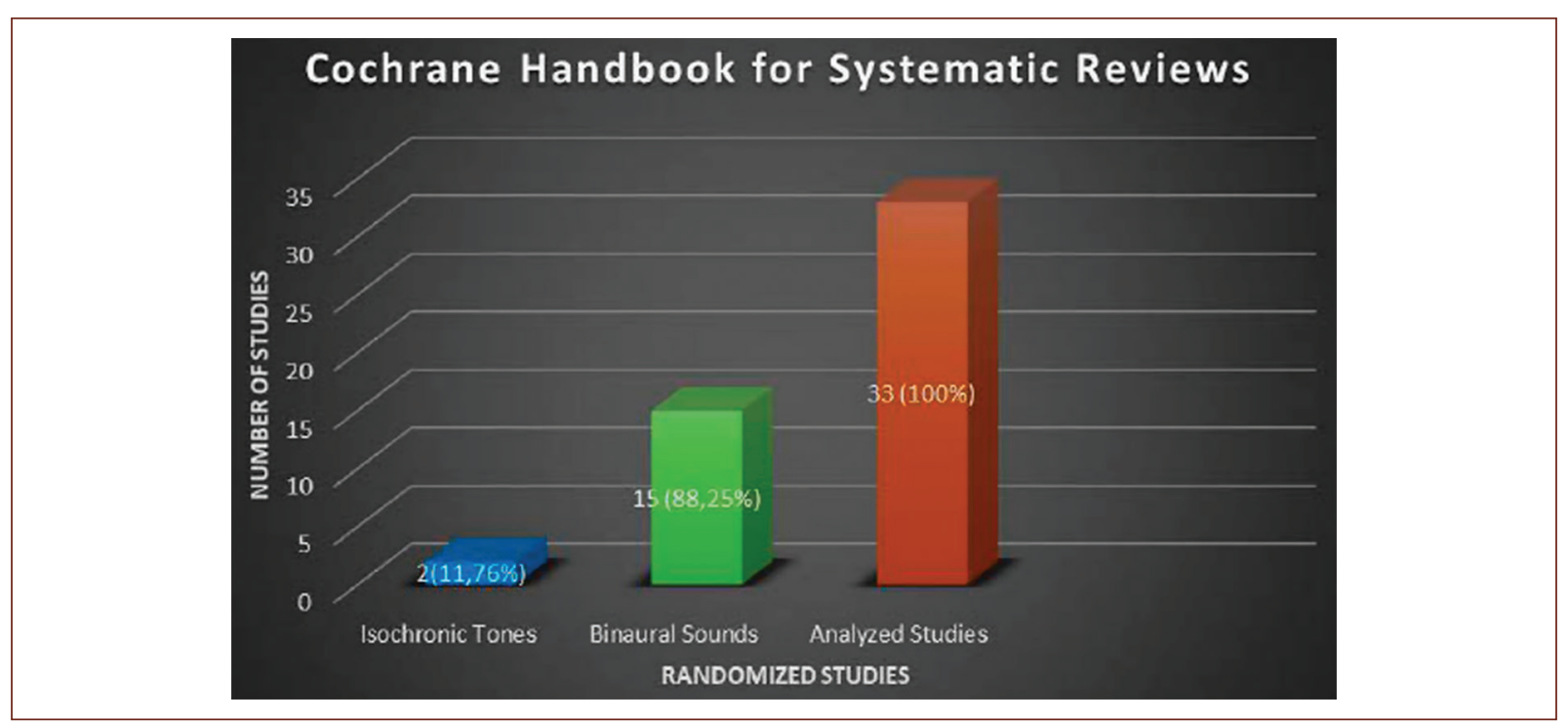

Figure 3. Summary of the selected studies - handbook for systematic reviews.

activation and self-reported relaxation ${ }^{30}$. Finally, a single intervention with isochronic tones at 6,10 and $40 \mathrm{~Hz}$ during 5 min reduced anxiety and improved well-being reports of healthy individuals ${ }^{31}$.

Alpha waves $(8-13 \mathrm{~Hz})$ : this frequency pattern is related to mental relaxation ${ }^{32}$, visualization, and creative processes; therapeutically uses include memory optimization, and modulation of pain perception threshold. The use of this wave pattern in the elderly population has been shown an excellent therapeutic potential to treat memory disorders ${ }^{33}$.

Alpha waves were used with a therapeutic and/or neurocognitive focus in six studies reviewed here.
Vernon et al..$^{34}$ reported that $10 \mathrm{~Hz}$ alpha pattern for 1 or 5 min did not elicit significant EEG alteration. However, isochronic stimulation with $7 \mathrm{~Hz}$ for 9 min with 3 min intervals induced temporal and parietal lobe activation with the potential to alter brain networks in adult's healthy young individuals ${ }^{35}$. Alpha binaural beats for 3 min in healthy young adults did not affect attentional blink (AB) control with the EBR method (predictor of mood states associated with dopamine levels $)^{36}$. Moreover, patients with temporal lobe epilepsy who underwent brain implants, the acute exposure to $10 \mathrm{~Hz}$ isochronic tones for $5 \mathrm{~min}$ increased significantly medio temporal synchronization ${ }^{17,30}$. 


\section{S. Aparecido-Kanzler, et al.: Binaural and isochronic tones in brain}

Table 1. Summary of the main findings of the 17 selected studies according to the therapeutic use of binaural beats and isochronic tones auditory brainwave entrainment

\begin{tabular}{|c|c|c|c|c|}
\hline Study & $\begin{array}{l}\text { Method and Sample } \\
\text { size (N) }\end{array}$ & Population//ype/Special? & $\begin{array}{l}\text { Number of interventions and } \\
\text { frequency }\end{array}$ & Outcomes \\
\hline $\begin{array}{l}\text { Kennel et al., } \\
2010^{44}\end{array}$ & $\mathrm{R}+\mathrm{DB}+\mathrm{PC} ; 20$ & $\begin{array}{l}\text { Male and female children } \\
\text { and adolescents with } \\
\text { Attention-deficit/ } \\
\text { hyperactivity disorder }\end{array}$ & $\begin{array}{l}3 \text { weeks with three interventions } \\
\text { per week with binaural beta- } 16 \\
\mathrm{~Hz} \text { - beats } 10 \mathrm{~min}\end{array}$ & $\begin{array}{l}\text { Improved focus and } \\
\text { attention }\end{array}$ \\
\hline $\begin{array}{l}\text { Vernon et al., } \\
2014^{34}\end{array}$ & $R, 22$ & $\begin{array}{l}\text { Healthy male and female } \\
\text { young adults }\end{array}$ & $\begin{array}{l}\text { Acute intervention (single): } \\
10 \mathrm{~Hz} \text { (Alpha) } \\
20 \mathrm{~Hz} \text { (Beta) }\end{array}$ & $\begin{array}{l}\text { Induced brainwave } \\
\text { entrainment }\end{array}$ \\
\hline $\begin{array}{l}\text { McConnell et al., } \\
2014^{30}\end{array}$ & $\mathrm{R}+\mathrm{DB}+\mathrm{PC}, 21$ & $\begin{array}{l}\text { Young adults post- } \\
\text { exercise }\end{array}$ & $\begin{array}{l}\text { Single post-workout } \\
\text { intervention of } 4-7 \mathrm{~Hz} \text { theta } \\
\text { waves }\end{array}$ & $\begin{array}{l}\text { Increased } \\
\text { parasympathetic } \\
\text { activation, increased } \\
\text { sympathetic withdrawal, } \\
\text { and increased } \\
\text { self-reported relaxation } \\
\text { after exercise }\end{array}$ \\
\hline $\begin{array}{l}\text { Becher et al., } \\
2015^{17}\end{array}$ & $\mathrm{R}+\mathrm{PC}, 10$ & $\begin{array}{l}\text { Patients with temporal } \\
\text { lobe epilepsy }\end{array}$ & $\begin{array}{l}\text { Acute pre-surgical intervention, } \\
\text { the duration of the main } \\
\text { experiment varied between } 15 \\
\text { and } 40 \text { min, and the total } \\
\text { number of auditory stimuli } \\
\text { varied between } 87 \text { and } 214 \mathrm{~Hz}\end{array}$ & $\begin{array}{l}\text { Increased intracranial } \\
\text { flow modulation in } \\
\text { patients with temporal } \\
\text { lobe epilepsy }\end{array}$ \\
\hline $\begin{array}{l}\text { Reedjik et al., } \\
2015^{36}\end{array}$ & $\mathrm{R}+\mathrm{PC}, 24$ & $\begin{array}{l}\text { Healthy male and female } \\
\text { young adults }\end{array}$ & $\begin{array}{l}\text { Applications of binaural } \\
\text { frequencies of gamma } \\
\text { frequency }(40 \mathrm{~Hz}) \text { and alpha } \\
\text { ( } 10 \mathrm{~Hz}) \text {, for } 3 \mathrm{~min} \text { before and } \\
\text { during a global-local task }\end{array}$ & $\begin{array}{l}\text { Measurement and } \\
\text { control of attentional } \\
\text { blink (AB), EBR method } \\
\text { (predictor of dopamine } \\
\text { levels and mood states) }\end{array}$ \\
\hline $\begin{array}{l}\text { Tirdad et al., } \\
2015^{35}\end{array}$ & $\mathrm{R}+\mathrm{PC}, 15$ & $\begin{array}{l}\text { Healthy male and female } \\
\text { young adults }\end{array}$ & $\begin{array}{l}\text { Intermittent intervention of } \\
3 \text { min with } 1 \text { min of intertrial } \\
\text { interval, } 7 \mathrm{~Hz} \text { applications of } \\
\text { binaural tones during } 9 \text { min }\end{array}$ & $\begin{array}{l}\text { Promoted brainwave } \\
\text { entrainment }\end{array}$ \\
\hline $\begin{array}{l}\text { Colzato et al., } \\
2016^{54}\end{array}$ & $\mathrm{R}+\mathrm{PC}+\mathrm{DB}, 40$ & $\begin{array}{l}\text { Healthy male and female } \\
\text { adults }\end{array}$ & $\begin{array}{l}\text { Single } 40 \mathrm{~Hz} \text { gamma binaural } \\
\text { beat intervention }\end{array}$ & $\begin{array}{l}\text { Improved selective } \\
\text { attention }\end{array}$ \\
\hline $\begin{array}{l}\text { Zampi, } \\
2016^{16}\end{array}$ & $\mathrm{R}+\mathrm{PC}, 36$ & Chronic pain patients & $\begin{array}{l}\text { Sequential intervention for } \\
14 \text { days with Theta } 6 \mathrm{~Hz}\end{array}$ & $\begin{array}{l}\text { Attenuated severity of } \\
\text { pain }\end{array}$ \\
\hline $\begin{array}{l}\text { Beaucheneet al., } \\
2016^{28}\end{array}$ & $\mathrm{R}+\mathrm{PC}, 28$ & $\begin{array}{l}\text { Healthy male and female } \\
\text { young adults }\end{array}$ & $\begin{array}{l}\text { Acute intervention (single) with } \\
\text { six acoustic stimulation } \\
\text { conditions: None, Pure Tone, } \\
\text { Classical Music, } 5 \mathrm{~Hz}, 10 \mathrm{~Hz} \\
\text { and } 15 \mathrm{~Hz} \text { binaural beats }\end{array}$ & $\begin{array}{l}\text { Improved visuospatial } \\
\text { working memory } \\
\text { performance and } \\
\text { cortical connectivity }\end{array}$ \\
\hline $\begin{array}{l}\text { Beauchene et al., } \\
2017^{29}\end{array}$ & $\mathrm{R}+\mathrm{PC}, 34$ & $\begin{array}{l}\text { Healthy male and female } \\
\text { young adults }\end{array}$ & $\begin{array}{l}\text { Acute intervention (single) with } \\
\text { six acoustic stimulation } \\
\text { conditions: None, Pure Tone, } \\
\text { Classical Music, } 5 \mathrm{~Hz}, 10 \mathrm{~Hz} \\
\text { and } 15 \mathrm{~Hz} \text { binaural beats }\end{array}$ & $\begin{array}{l}\text { Improved working } \\
\text { memory performance }\end{array}$ \\
\hline $\begin{array}{l}\text { Colzato et al., } \\
2017^{53}\end{array}$ & $\mathrm{R}+\mathrm{PC}+\mathrm{DB}, 36$ & $\begin{array}{l}\text { Healthy male and female } \\
\text { young adults }\end{array}$ & $\begin{array}{l}\text { Acute intervention (single) } \\
\text { applications of binaural } \\
\text { frequencies of gamma frequency } \\
(40 \mathrm{~Hz}) \text {, for } 3 \text { min before and } \\
\text { during a global-local task }\end{array}$ & $\begin{array}{l}\text { High frequency binaural } \\
\text { beats improved the } \\
\text { attention }\end{array}$ \\
\hline $\begin{array}{l}\text { Lopez-Caballero } \\
\text { and Escera, } \\
2017^{58}\end{array}$ & $\mathrm{R}+\mathrm{PC}, 40$. & $\begin{array}{l}\text { Healthy male and female } \\
\text { young adults }\end{array}$ & $\begin{array}{l}\text { Beats of } 5 \text { different frequencies } \\
\text { (4.53 Hz - theta -, } 8.97 \mathrm{~Hz} \\
\text {-alpha-, } 17.93 \mathrm{~Hz} \text {-beta-, } 34.49 \\
\mathrm{~Hz} \text {-gamma -or } 57.3 \mathrm{~Hz} \text {-super- } \\
\text { gamma) binaurally and } \\
\text { acoustically for } 3 \text { min, preceded } \\
\text { and followed. For periods of } \\
\text { white noise of } 90 \mathrm{~s} \text { (baseline } \\
\text { and post values, respectively) }\end{array}$ & $\begin{array}{l}\text { Promoted brainwave } \\
\text { entrainment }\end{array}$ \\
\hline
\end{tabular}


Table 1. Summary of the main findings of the 17 selected studies according to the therapeutic use of binaural beats and isochronic tones auditory brainwave entrainment (Continued)

\begin{tabular}{|c|c|c|c|c|}
\hline Study & $\begin{array}{l}\text { Method and Sample } \\
\text { size (N) }\end{array}$ & Population//ype/Special? & $\begin{array}{l}\text { Number of interventions and } \\
\text { frequency }\end{array}$ & Outcomes \\
\hline $\begin{array}{l}\text { Nantawachara } \\
\text { Jirakittayakorn, } \\
2017^{52}\end{array}$ & $\mathrm{R}+\mathrm{PC}, 40$ & $\begin{array}{l}\text { Healthy male and female } \\
\text { young adults }\end{array}$ & $\begin{array}{l}\text { Applications binaural beats of } \\
\text { gamma frequency }(40 \mathrm{~Hz}) \text {, for } \\
20 \text { min before and after } \\
\text { global-local task }\end{array}$ & $\begin{array}{l}\text { Improved working } \\
\text { memory function } \\
\text { assessed by the word } \\
\text { list retrieval task }\end{array}$ \\
\hline $\begin{array}{l}\text { Chaieb et al., } \\
2015^{55}\end{array}$ & $R+P C ; 15$ & $\begin{array}{l}\text { Epilepsy in pre-surgical } \\
\text { situation } \\
\text { Male and female adults. }\end{array}$ & $\begin{array}{l}6 \text { interventions } \\
1 \text { time per week, } 5 \mathrm{~Hz} \text { theta } \\
\text { binaural tones, } 6 \mathrm{~min} \text { with } 3.5 \mathrm{~s} \\
\text { and } 5 \mathrm{~s} \text { intervals. }\end{array}$ & $\begin{array}{l}\text { Improved long-term } \\
\text { memory in epileptic } \\
\text { patients }\end{array}$ \\
\hline $\begin{array}{l}\text { Chaieb et al., } \\
2017^{31}\end{array}$ & $\mathrm{R}+\mathrm{PC} ; 25$ & $\begin{array}{l}\text { Male and female young } \\
\text { adults }\end{array}$ & $\begin{array}{l}\text { Single progressive intervention } \\
\text { with isochronic tones } 6 \mathrm{HZ} \text { theta, } \\
10 \mathrm{HZ} \text { alpha, and } 40 \mathrm{HZ} \text { gamma }\end{array}$ & $\begin{array}{l}\text { Reduced anxiety levels } \\
\text { (modulation of mental } \\
\text { states) }\end{array}$ \\
\hline $\begin{array}{l}\text { Gálvez et al., } \\
2017^{43}\end{array}$ & $\mathrm{R}+\mathrm{DB}+\mathrm{PC}, 14$ & $\begin{array}{l}\text { Parkinson's disease } \\
\text { patients }\end{array}$ & $\begin{array}{l}2 \text { randomized and } \\
\text { counterbalanced sessions of } \\
\text { sound stimulation ( } 14 \mathrm{~Hz} \\
\text { binaural beats) for } 10 \mathrm{~min} \\
\text { separated by a minimum of } 7 \\
\text { days of interval }\end{array}$ & $\begin{array}{l}\text { Improved motor and } \\
\text { non-motor symptoms } \\
\text { including anxiety } \\
\text { symptoms and } \\
\text { cognitive deficits }\end{array}$ \\
\hline $\begin{array}{l}\text { Garcia-Argibay } \\
\text { et al., } \\
2017^{27}\end{array}$ & $\mathrm{R}+\mathrm{PC}, 32$ & $\begin{array}{l}\text { Healthy male and female } \\
\text { adults }\end{array}$ & $\begin{array}{l}\text { Single intervention of } 5 \mathrm{~Hz} \text { theta } \\
\text { waves and another group with } \\
20 \mathrm{~Hz} \text { Beta }\end{array}$ & $\begin{array}{l}\text { Improved long-term } \\
\text { memory and attention }\end{array}$ \\
\hline
\end{tabular}

R: randomized study; DB: double-blinded study; PC: placebo-controlled study.

Beta waves (13-39 Hz): this frequency pattern is related to attention, focus, concentration, and cognition. Beta BWE was shown to be effective in improving fatigue and some symptoms of attention deficit hyperactive disorder (ADHD), including learning and attention deficits. Additional studies showed improvement in visual acuity, coordination, potential for the dyslexia treatment and low of concentration, as well as, to promote IQ gain in the range of 8-10 points ${ }^{37}$. Beta wave entrainment influenced self-confidence and socialization and makes people more optimistic and energetic ${ }^{38-41}$. Finally, it helps learning as well as sports-related abilities $^{3,42}$.

Five independent studies reviewed here used beta waves. Beauchene et al. ${ }^{28}$ demonstrated that $15 \mathrm{~Hz}$ beta pattern for 5 min increased short-term visuospatial working memory and cortical connectivity in healthy young subjects. A single 15-min session of $20 \mathrm{~Hz}$ significantly increased long-term memory, improving the codification of new information without previous memories $^{24}$. Interestingly, Vernon et al. ${ }^{34}$ demonstrated that two daily sessions (14 Hz, during $10 \mathrm{~min}$ ) increased motor and non-motor symptoms in Parkinson's disease (PD) patients. In addition, Gálvez et al. ${ }^{43}$ showed a decrease of functional connectivity and optimization of working memory, with no changes in gait or anxiety levels in PD patients in comparison to control group. Kennel et al. ${ }^{44}$ submitted a group of children and adolescents with diagnosis of ADHD to brain entrainment sessions (duration of $10 \mathrm{~min}, 3$ days per week for 3 weeks). Results were not totally conclusive, although parents reported improvement in the performance of homework tasks after the interventions.

Gamma Waves (> $40 \mathrm{~Hz}$ ): this frequency pattern is involved in blinking and processing of information from all parts of the brain. High gamma wave activity in the brain is associated with intelligence, compassion, self-control, and feelings of happiness ${ }^{45-48}$. In addition, gamma brainwaves have been associated with improved memory and a greater ability of reality perception $^{49,50}$. Gamma brainwave activity has been shown to be increased in monks during meditation ${ }^{51}$.

Six studies were conducted with gamma BWE. It was demonstrated that $40 \mathrm{~Hz}$ gamma stimulation for $20 \mathrm{~min}$ improved working memory performance and mnemonic function in healthy subjects ${ }^{52}$. $A B$ control, using the EBR method (predictor of mood states associated with dopamine levels), was significantly affected by $3-\mathrm{min}$ binaural gamma stimulation in healthy young adults, before and during a global-local task ${ }^{36}$. These benefits 
Table 2. Summary of therapeutic applications of different brain waves patterns

\begin{tabular}{|c|c|c|c|}
\hline Type of intervention & Method & Time & Wave frequency range \\
\hline Isochronic tones $5,10,40$ and $80 \mathrm{~Hz}$ & $\begin{array}{l}\text { Acute } \\
\text { Single sequential }\end{array}$ & 15 to $40 \mathrm{~min}$ & $\begin{array}{l}\text { Theta, alpha, beta, gamma, and super } \\
\text { gamma }\end{array}$ \\
\hline Isochronic tones 6,10 and $40 \mathrm{~Hz}$ & $\begin{array}{l}\text { Acute } \\
\text { Single sequential }\end{array}$ & $5 \min$ & Alpha, beta, and gamma \\
\hline Binaural 5,10 and $15 \mathrm{~Hz}$ & $\begin{array}{l}\text { Acute } \\
\text { Single sequential }\end{array}$ & $5 \mathrm{~min}$ & Theta, alpha and beta \\
\hline Binaural $40 \mathrm{~Hz}$ & $\begin{array}{l}\text { Acute } \\
\text { Single sequential }\end{array}$ & $20 \mathrm{~min}$ & Gamma \\
\hline Binaural 5 and $20 \mathrm{~Hz}$ & $\begin{array}{l}\text { Acute } \\
\text { Single sequential }\end{array}$ & $15 \mathrm{~min}$ & Theta and beta \\
\hline Binaural 10 and $20 \mathrm{~Hz}$ & $\begin{array}{l}\text { Acute } \\
\text { Single alternate }\end{array}$ & $1 \mathrm{~min}$ & Alpha and beta \\
\hline Binaural $7 \mathrm{~Hz}$ & $\begin{array}{l}\text { Acute } \\
\text { Single }\end{array}$ & $9 \min$ & Theta \\
\hline Binaural 10 and $40 \mathrm{~Hz}$ & $\begin{array}{l}\text { Acute } \\
\text { Single alternate }\end{array}$ & $3 \mathrm{~min}$ & Alpha and gamma \\
\hline Binaural $40 \mathrm{~Hz}$ & $\begin{array}{l}\text { Acute } \\
\text { Single }\end{array}$ & $10 \mathrm{~min}$ & Gamma \\
\hline Binaural $5,10,40$ and $80 \mathrm{~Hz}$ & $\begin{array}{l}\text { Acute } \\
\text { Single sequential }\end{array}$ & $15-40 \mathrm{~min}$ & $\begin{array}{l}\text { Theta, alpha, beta, gamma, and super } \\
\text { gamma }\end{array}$ \\
\hline Binaural 4 a $7 \mathrm{~Hz}$ & $\begin{array}{l}\text { Acute } \\
\text { Single sequential }\end{array}$ & $20 \mathrm{~min}$ & Theta \\
\hline Binaural $5 \mathrm{~Hz}$ & $\begin{array}{l}\text { Chronic } \\
3 \text { repetitions per week for } \\
6 \text { weeks }\end{array}$ & $6 \min$ & Theta \\
\hline Binaural $6 \mathrm{~Hz}$ & $\begin{array}{l}\text { Chronic } \\
2 \text { daily repetitions for } 14 \text { days }\end{array}$ & $20 \mathrm{~min}$ & Theta \\
\hline Binaural $14 \mathrm{~Hz}$ & $\begin{array}{l}\text { Chronic } \\
2 \text { repetitions a day for } 7 \text { days }\end{array}$ & $10 \mathrm{~min}$ & Beta \\
\hline Binaural beta - performance range & $\begin{array}{l}\text { Chronic } \\
3 \text { repetitions per week for } \\
3 \text { weeks }\end{array}$ & $10 \mathrm{~min}$ & Beta \\
\hline
\end{tabular}

were observed only in individuals with low rates of spontaneous blinking, which indicates low levels of dopamine in the striatum. Colzato et al. ${ }^{53}$ reported that 3-min $40 \mathrm{~Hz}$ binaural beats stimulation improved focus and attention in healthy young adults. Moreover, a study using 10-min $40 \mathrm{~Hz}$ stimulation in healthy adults ${ }^{54}$ demonstrated that BWE acts by modeling specific brain oscillations, in cognitive processes sustained in the gamma wave frequency range, such as mental processes related to intelligence, self-control, and well-being. In epileptic patients subjected to brain implants, acute isochronic tones and binaural beats exposure, in the range of $40-80 \mathrm{~Hz}$ for 5 min significantly decreased synchronization in medio-temporal sites, demonstrating their potential as a non-invasive therapy for modulating intracranial flow in synchronization of the EEG signals ${ }^{17}$. A single intervention with isochronic tones 6,10 , and $40 \mathrm{~Hz}$ over 5 min reduced anxiety and, consequently, increased the subjects' well-being, however, without marked effects on cognition ${ }^{55}$.

As illustrated in figure 3, in $82.35 \%$ of the reviewed studies, monaural, and/or binaural audio stimulation were more effective in comparison to control group. As previously mentioned, binaural beats were used as therapeutic modality in 15 studies (88.25\%), and isochronic tones were only used in two studies (11.76\%). 


\section{Discussion}

The data reviewed in the present study indicates that binaural beats are more commonly used than isochronic tones, at least in research (as seen in Fig. 3). Unfortunately, in our view, there is no standard in the choice of therapy parameters, such as brainwave range (in $\mathrm{Hz}$ ), treatment duration, frequency, and regimen, neither for the treatment of specific conditions or disorders, nor for simple increase of executive brain functions and stimulation of inherent mental processes, and neurocognitive performance. A relevant observation is the absence of properly controlled double-blinded studies, which compromises the validity of the results available in the literature. Nevertheless, the results reviewed here suggest that auditory BWE, although still scarcely explored in behavioral and neurophysiological therapy, may represent an effective and inexpensive therapeutic approach, with minimal side effects. It is well known that all brain activity occurs through the bioelectric activity of neural networks and that the brain wave phenomenon is produced as a result of the sum of bioelectric interactions of the billions of neurons and their trillions of synaptic connections ${ }^{56}$. Changes in states of consciousness (concentration, excitement, relaxation, sleep, dreams, etc.) are closed related to changes in the frequency of the vibratory pattern of brain waves, which varies according to the intensity of these bioelectric activities.

According to this system and considering that our state of consciousness is influenced by brain wave patterns, it is plausible to conclude that BWE can modulate many aspects of behavior, from states of consciousness to perception, learning, and cognition ${ }^{57}$.

The adaptation to daily activities requires the brain ability to modulate brain wave activity, in consonance to external stimuli and signals, as well as when faced with challenges and/or problems to be solved. Each type of brain wave can modulate different neurotransmitter systems, inducing particular synaptic and neurochemical readjustments ${ }^{12,56}$.

\section{Conclusions}

Based on the data reviewed in this study, binaural beats and isochronic tones BWE may effectively modulate mood states, improving attention, and memory processes. Promising results were also obtained in subjects suffering from different CNS disorders, including ADHD, PD, epilepsy, chronic pain, and anxiety disorders.
Despite the audio BWE effectiveness described in many studies reviewed here, it is important to emphasize that some positive outcomes may require further investigation, with more refined and appropriate evaluation tools, better suited for each specific type of intervention, and/or therapeutic target. Considering these limitations, the performance of additional studies with more adequate experimental design and data analysis is recommended, particularly focusing on the neurophysiological and behavioral effects of brain wave entrainment on mental states.

\section{Acknowledgments}

The authors would like to thank the Experimental Laboratory of Neurodegenerative Diseases - LEXDON, Federal University of Santa Catarina - UFSC.

\section{Funding}

This research did not receive any specific grants from agencies in the public, commercial, or non-profit sectors.

\section{Conflicts of interest}

The authors declare that they have no conflicts of interest.

\section{Ethical disclosures}

Protection of human and animal subjects. The authors declare that no experiments were performed on humans or animals for this study.

Confidentiality of data. The authors declare that no patient data appear in this article.

Right to privacy and informed consent. The authors declare that no patient data appear in this article.

\section{References}

1. Frank MG, Brain Rhythms. In: Binder MD, Hirokawa N, Windhorst $U$, editors. Encyclopedia of Neuroscience. Berlin, Heidelberg: Springer; 2008

2. Rechtschaffen A, Kales A. A Manual of Standardized Terminology, Techniques and Scoring System for Sleep Stages of Human Subjects. LoS Angeles (Calif.): University of California. Brain Research Institute; 1968

3. Siever D. The application of audiovisual entrainment for the treatment of seasonal affective disorder. Biofeedback. 2004:32:32-5

4. Gruzelier JH. New advances in EEG and cognition. Int J Psychophysiol. 1996;24:1-5.

5. Foster DS. EEG and Subjective Correlates of Alpha Frequency Binaural Beats Stimulation Combined with Alpha Biofeedback. Ann Arbor, MI: UMI; 1990.

6. Kennerly RC. An Empirical Investigation into the Effect of Beta Frequency Binaural Beat Audio Signals on Four Measures of Human Memory. Carrolton, Georgia: Department of Psychology, West Georgia College; 1994. Available from https://www.iawakepro.com/an-empirical-investigation-into-the-effect-of-beta-frequency-binaural-beat-audio-signals-onfour-measures-of-human-memory. 


\section{S. Aparecido-Kanzler, et al.: Binaural and isochronic tones in brain}

7. Le Scouranec RP, Poirier RM, Owens JE, Gauthier J, Taylor AG Foresman PA. Use of binaural beat tapes for treatment of anxiety: a pilot study of tape preference and outcomes. Altern Ther. 2001;7:58-63.

8. Granada $A E$, Herzel $\mathrm{H}$. How to achieve fast entrainment? The timescale to synchronization. PLoS One. 2009;4:e7057.

9. Huygens $\mathrm{C}$. Horologium Oscillatorium sive de motu pendulorum ad horologia aptato demonstrationes geometricae. Paris, France: Apud F. Muguet; 1673. The Pendulum Clock Ames: lowa State University Press; 1986.

10. Oster G. Auditory beats in the brain. Sci Am. 1973;229:94-102

11. Cannon J, McCarthy MM, Lee S, Lee J, Börgers C, Whittington MA, et al Neurosystems: brain rhythms and cognitive processing. Eur J Neurosci. 2014;39:705-19

12. Bear M, Connors BW, Paradiso MA. Unraveling the Nervous System. $10^{\text {th }}$ ed. Porto Alegre, Brazil: Artmed; 2017.

13. Apa-Soeta $Y$, Nakagawa $S$. Effects of the binaural auditory filter in the human brain. Neuro Report. 2007;18:1939-43.

14. Monroe RA, Gabbard GO, Jones FC, Twemlow SW. Far Journeys. Garden City, NY: Doubleday; 1985.

15. Kasprzak C. Influence of binaural beats on EEG signal. Acta Phys Pol. 2011;119:986-90.

16. Zampi DD. Efficacy of theta binaural beats for the treatment of chronic pain. Altern Ther Health Med. 2016;22:32-8.

17. Becher AK, Höhne M, Axmacher N, Chaieb L, Elger CE, Fell J. Intracranial electroencephalography power and phase synchronization changes during monaural and binaural beat stimulation. Eur $J$ Neurosci. 2015;41:254-63.

18. Jirakittayakorn $\mathrm{N}$, Wongsawat $\mathrm{Y}$. The brain responses to different frequencies of binaural sounds on QEEG at cortical level. Conf Proc IEEE Eng Med Biol Soc. 2015;4687-91.

19. Higgins J, Thomas J, editors. Cochrane Handbook for Systematic Reviews of Interventions; 2019. Available from: https://www.training.cochrane.org/handbook/current. [Last accessed on 2019 Oct 12].

20. Jadad AR, Moore RA, Carroll D, Jenkinson C, Reynolds DJ, Gavaghan DJ, et al. Assessing the quality of reports of randomized clinical trials: is blinding necessary? Control Clin Trials. 1996;17:1-12.

21. Washington P, Pit-Claudel B, Paredes P. Mental Health Interventions through Brain Wave Oscillations. In: Proceedings of SIGCHI 19 (Computing and Mental Health Symposium). New York: ACM; 2019.

22. Szentirmai E, Yasuda T, Taishi $P$, Wang M, Churchill L, Bohnet $S$, et al Growth hormone-releasing hormone: cerebral cortical sleep-related EEG actions and expression. Am J Physiol Regul Integr Comp Physiol. 2007;293:R922-30.

23. Botella-Soler V, Valderrama M, Benoît C, Navarro M, Quyen LV. Large-scale cortical dynamics of sleep slow waves. PLoS One. 2012; 7:e30757.

24. Wickramasekera IE. On attempts to modify hypnotic susceptibility: some psychophysiological procedures and promising directions. Ann N Y Acad Sci. 1977;296:143-53

25. Sabourin M, Cutcomb SD, Crawford HJ, Pribram K. EEG correlates of hypnotic susceptibility and hypnotic trance: spectral analysis and coherence Int J Psychophysiol. 1990;10:125-42.

26. Derner M, Chaieb L, Surges R, Staresina BP, Fell J. Modulation of item and source memory by auditory beat stimulation: a pilot study with intracranial EEG. Front Hum Neurosci. 2018;12:500.

27. Garcia-Argibay M, Santed MA, Reales JM. Binaural Auditory beats affect long-term memory. Psychol Res. 2019;83:1124-36.

28. Beauchene C, Abaid N, Moran R, Diana RA, Leonessa A. The effect of binaural beats on visuospatial working memory and cortical connectivity. PLoS One. 2016;11:e0166630.

29. Beauchene C, Abaid N, Moran R, Diana RA, Leonessa A. The effect of binaural beats on verbal working memory and cortical connectivity J Neural Eng. 2017; 14:026014.

30. McConnell PA, Froeliger B, Garland EL, Ives JC, Sforzo GA. Auditory driving of the autonomic nervous system: listening to theta-frequency binaural beats post-exercise increases parasympathetic activation and sympathetic withdrawal. Front Psychol. 2014;5:1248.

31. Chaieb L, Wilpert EC, Hoppe C, Axmacher N, Fell J. The impact of monaural beat stimulation on anxiety and cognition. Front Hum Neurosci. $2017 ; 11: 251$
32. Bhat P. Efficacy of Alfa EEG wave biofeedback in the management of anxiety. Ind Psychiatry J. 2010;19:111-4.

33. Klimesch W. EEG alpha and theta oscillations reflect cognitive and memory performance: a review and analysis. Brain Res Brain Res Rev. 1999;29:169-95

34. Vernon D, Peryer G, Louch J, Shaw M. Tracking EEG changes in response to alpha and beta binaural beats. Int J Psychophysiol. 2014:93:134-9.

35. Tirdad SA, Ahmadi-Pajouh MA, Nasrabadi AM. Cumulative effects of theta binaural beats on brain power and functional connectivity. Biomed Sig Proc Control 2018;42:242-52.

36. Reedijk SA, Bolders A, Colzato LS, Hommel B. Eliminating the attentional blink through binaural beats: a case for tailored cognitive enhancement. Front Psychiatry. 2015;6:82.

37. Brenner RP, Ulrich RF, Spiker DG, Sclabassi RJ, Reynolds CF $3^{\text {rd }}$ Marin RS, et al. Computerized EEG spectral analysis in elderly normal, demented and depressed subjects. Electroencephalogr Clin Neurophysiol. 1986;64:483-92.

38. Hauri P. Treating psychophysiologic insomnia with biofeedback. Arch Gen Psychiatry. 1981;38:752-8.

39. Howard CE, Graham LE $2^{\text {nd }}$, Wycoff SJ. A comparison of methods for reducing stress among dental students. J Dent Educ. 1986;50:542-4.

40. Graham J. Patrick RN. Improved neuronal regulation in ADHD. J Neurother. 1996;1:27-36.

41. Egner T, Gruzelier JH. EEG biofeedback of low beta band components: frequency-specific effects on variables of attention and event-related brain potentials. Clin Neurophysiol. 2004;115:131-9.

42. Neto JD. Neurofeedback How Neuropsicoterapia Appeal to The Deficit Disorder Attention with or Without Hyperactivity and Impulsivity. Teresina, Brazil: Revista FSA (Faculdade Santo Agostinho); 2012.

43. Gálvez G, Recuero M, Canuet L, Del-Pozo F. Short-term effects of binaural beats on EEG power, functional connectivity, cognition, gait and anxiety in parkinson's disease. Int J Neural System. 2018;28:1750055.

44. Kennel S, Taylor AG, Lyon D, Bourguignon C. Pilot feasibility study of binaural auditory beats for reducing symptoms of inattention in children and adolescents with attention-deficit/hyperactivity disorder. J Pediatr Nurs. 2010;25:3-11.

45. Munk MH, Roelfsema PR, König P, Engel AK, Singer W. Role of reticular activation in the modulation of intracortical synchronization. Science. 1996;272:271-4.

46. Burle B, Bonnet M. High-speed memory scanning: a behavioral argument for a serial oscillatory model. Brain Res Cogn Brain Res. 2000;9:327-37.

47. John ER, Prichep LS, Kox W, Valdés-Sosa P, Bosch-Bayard J Aubert E et al. Invariant reversible QEEG effects of anesthetics. Conscious Cogn. 2001;10:165-83

48. Davidson RJ, McEwen BS. Social influences on neuroplasticity: stress and interventions to promote well-being. Nat Neurosci. 2012:15:689-95.

49. Miltner WH, Braun C, Arnold M, Witte H, Taub E. Coherence of gamma-band EEG activity as a basis for associative learning. Nature. 1999;397:434-6.

50. Crone NE, Hao L, Hart J Jr., Boatman D, Lesser RP, Irizarry R, et al. Electrocorticographic gamma activity during word production in spoken and sign language. Neurology. 2001;57:2045-53.

51. Benson H. Transcendental meditation science or cult? JAMA. 1974;227:807.

52. Jirakittayakorn $\mathrm{N}$, Wongsawat $\mathrm{Y}$. Brain responses to $40-\mathrm{Hz}$ binaural beat and effects on emotion and memory. Int J Psychophysiol. 2017;120:96-107.

53. Colzato LS, Steenbergen L, Sellaro R. The effect of gamma-enhancing binaural beats on the control of feature bindings. Exp Brain Res. 2017;235:2125-31.

54. Colzato LS, Barone H, Sellaro R, Hommel B. More attentional focusing through binaural beats: evidence from the global-local task. Psychol Res. 2017:81:271-7.

55. Chaieb L, Leszczynski M, Axmacher N, Höhne M, Elger CE, Fell J. Theta-gamma phase-phase coupling during working memory maintenance in the human hippocampus. Cogn Neurosci. 2015;6:149-57.

56. Lent, R, One Hundred Billion Neurons: Fundamental Concepts of Neuroscience. São Paulo: Atheneu; 2004.

57. Poulet JF, Fernandez LM, Crochet S, Petersen CC. Thalamic control of cortical states. Nat Neurosci. 2012;15:370-2

58. López-Caballero F, Escera C. Enhancement of gamma-band electroencephalographic activity (solely) by binaural beats Binaural beat: a failure to enhance EEG power and emotional arousal. Front Hum Neurosci. 2017; $11: 557$. 